DOI: $10.4274 /$ tpa. 46.48

\title{
Ergende adneksiyal kitleye yaklaşım
}

\section{Clinical approach to adnexal masses in adolescence}

Hüsnü Gökaslan

Marmara Üniversitesi Tıp Fakültesi, Kadın Hastalıkları ve Doğum Anabilim Dalı, İstanbul, Türkiye

\begin{abstract}
Özet
Ergenlerde fonksiyonel ve fizyolojik over kisti oluşumları, spektrumun diğer ucundaki çok ciddi kötü huylu tümörlerle birlikte adneksiyal kitle grubunu oluşturmaktadır. Bu yelpazede fonksiyonel olduğu düşünülen olgularda öncelikli yaklaşım bekle-gör yaklaşımıdır. Kötü huylu over tümörlerinin büyük çoğunluğu germ hücreli tümörlerdir. Ergenlerde temel prensip organ ve fertilite koruyucu yaklaşımdır. Kötü huylu tümörlerde buna evreleme eklenmelidir. Yaygın tümörlerde ise tümörü ortadan kaldıran daha radikal organ ekstirpasyonları ve tümör küçültücü yaklaşım devreye girmektedir. Operasyon sonrası yaklaşım ise genel olarak cisplatin içeren bir kombinasyon kemoterapisidir. Bütün bu tedavileri uygularken ergenin gelişimi, psikolojisi, fertilitesinin korunması ve sonraki tedavi süreci de dikkate alınarak multidisipliner bir yaklaşım ön planda olmalıdır. (Türk Ped Arş 2011; 46 Özel Sayı: 111-4)
\end{abstract}

Anahtar sözcükler: Adneksiyal kitle, ergen, tanı, tedavi

\section{Summary}

The adnexal masses in adolescents contain functional and physiologic cystic formations on one end of the spectrum, and serious malignant tumors on the other end. The primary approach should be expectant management for the cysts which are thought to be benign in this spectrum. The most common malignant tumors in this era are germ cell tumors. The principal clinical approach in these tumors is to preserve organs and fertility. In malignant tumors a staging procedure should also be added. On the contrary, in disseminated tumors the primary surgery is cytoreductive or debulking surgery including radical organ extirpations. Post operative therapy is generally cis platin-containing combination chemotherapy. When tailoring management strategies, the development and psychology of the adolescent girls should be greatly considered as well as preserving fertility to be the ultimate aim of the treatment. Taking the subsequent therapy into consideration, a multidisciplinary approach should be the basis of the management of the malignant tumors of the adenexa. (Turk Arch Ped 2011; 46 Suppl: 111-4)

Key words: Adolescent, adnexal masses, diagnosis, treatment

\section{Giriş}

Premenopozal adneksiyal kitlelere yaklaşım şekli iyi bilinmektedir. Kitle boyutu 10 cm.'den az, mobil, kistik yapıda, tek taraflı ve malignite şüphesi bulunmayan kitlelerde 4-6 hafta süre ile bekle-gör yaklaşımı tercih edilir. Bu süre zarfında gonadotropinleri baskılamak ve over işlevlerini düzene sokmak düşüncesi ile östrojen ve progesteron içeren kombine oral kontraseptifler kullanılabilir. İzlem süresi sonunda kitle kaybolur ya da küçülürse klinik takibe devam edilir. Kitle sabit kalır ya da büyürse o zaman cerrahi eksplorasyon yapmak uygun olacaktır. Kitle çapı 10 cm.'den büyükse direk olarak cerrahi değerlendirme uygundur (1).
Ergenlerde yaklaşım premenopozal olgulardan farklıdır. Bu grupta yaklaşım prensiplerini anlayabilmek için pelvik kitlelerin özelliklerini bilmek yararlı olur. Over kaynaklı kitleler ergenlerde ön planda gelmektedir. Buna karşılık, uterustan kaynaklanan kitleler ise oldukça nadirdir. Ergende adneksiyal kitle ile karşılaşıldığında ilk olarak gebelik olasılığı düşünülmeli ve öncelikle dışlanmalıdır. Serum beta HCG değerine bakılarak klinik öncesi dönemde bile gebelik dışlanabilir. Klinik belirtiler arasında en sık karşımıza çıkanlar ağıı, baskı hissi ve üriner semptomlardır. Pelvik ve hatta abdominal kitle varlığı klinik bulgular arasında önde gelenlerdir (2).

Pelvik ağrı ile başvuran ve adneksiyal kitlesi bulunan 63 olguda yapılan bir çalışma, hangi histolojik tiplerle karşılaşılma

Yazışma Adresi/Address for Correspondence: Dr. Hüsnü Gökaslan,

Marmara Üniversitesi Tıp Fakültesi, Kadın Hastalıkları ve Doğum Anabilim Dalı, İstanbul, Türkiye

Türk Pediatri Arşivi Dergisi, Galenos Yayınevi tarafindan basılımıştr. / Turkish Archives of Pediatrics, Published by Galenos Publishing. 
olasılığı olduğunu ortaya koyması açısından önemlidir. Yaş ortalaması 15,36 $\pm 1,6$ olan bu ergen grupta 14 olgu fonksiyonel kist ön tanısı ile takip edilmiştir. Yirmi iki olgu ise neoplastik olmayan adneksiyal lezyon bulundurmaktadır. Gerekli olan 49 olguya cerrahi girişim uygulanmıştır. Cerrahi tedavi uygulanan olguların histolojik değerlendirme sonuçlarına bakıldığında \%26,5 oranında selim epitelyal over kisti, \%22,4 oranında matür kistik teratom ve \%4,08 oranında ise borderline over tümörü olduğu görülmektedir. Borderline olgu oranı oldukça düşüktür ve kötü huylu tümör bulunmamaktadır (3).

Ergen ve çocuklarda en sık rastlanan genital neoplazma over tümörüdür (Yıllık insidans= 2,6 / 100 000) (4). Başka bir açıdan bakıldığında overin kötü huylu tümörlerinin \%5'den azı ergen ve çocuklarda görülmektedir (2). Over tümörleri çocuklarda menarş öncesi ortaya çıkan tüm kanserlerin sadece \%1'ini oluşturur $(2,4)$. Ergende en sık rastlanan over tümörü germ hücreli tümör olup, 20 yaş altında yumurtalıkta bulunan tümörlerin yaklașık üçte ikisi germ hücreli tiptir. Ergenler çocuklarla birlikte değerlendirildiğinde bu grupta neoplazmaların \%35'i kötü huyludur (2).

Erişkinlerle karşılaştırıldığında germ hücreli tümörler ergenlerde bariz olarak sık görülür (\%60’a karşı \%20). Dokuz yaş altında saptanan neoplazmaların \%80 gibi büyük bir oranı kötü huyludur (2). Brenner tümörü dışında bütün over tümörü tiplerine menarş öncesi çocuklarda rastlanır. Tümörlerin en az \%30'u selim kistik teratomdur. Gençlerde over kanserlerinin \%70'inin germ hücre kökenli olduğu bilinmelidir (5 ).

Ergen ve çocuklarda over tümörlerinin çoğu iyi huyludur. İyi huylu tümörler $\% 77,2$, borderline tümörler $\% 7$ ve kötü huylu tümörler ise \%15,8 oranındadır (6). Giderek azalan sıklıkta over tümörlerinin histolojik tip dağılımı germ hücreli tümörler, epitelyal over tümörleri, stromal over tümörleri, lenfomalar ve mikst tümörler olup sırasıyla \%49,1, \%35,1, $\% 12,3$ ve son ikisi \%1,75 oranında bulunmuştur (6). Bütün kötü huylu tümörler içinde germ hücreli tümörlerin görülme oranı \%44,5'tir (6).

Embriyon döneminde germ hücreleri fetal yolk kesesinde üretilir ve primordial germ hücresi halini alırlar. Normal olarak buradan göç ederek karın boşluğunda böbreklerin komşuluğundaki gonad taslaklarına yerleşirler. Neoplastik dönüşüm bu hücrelerde ortaya çıkabilir. Anormal olarak farklı yerlere giden hücrelerin genellikle yaşam şansları olmaz ve hücre ölümü gerçekleşir. Yaşam şansı olanlarda ise neoplastik gelişim olasıdır. Ortaya çıkan neoplastik hücrelerin farklılaşması baskılanırsa germinom, seminom ve disgerminom oluşur. Embriyonal farklılaşma sonucunda ise embriyonal karsinom, matür ya da immatür teratom ortaya çıkar. Ekstraembriyonik farklılaşma ise endodermal sinüs tümörü ve koryokarsinom yönünde değişime yol açar $(7,8)$.

Adneksiyal kitlelerin bir bölümü hiçbir yakınmaya yol açmazlar ve ancak bir komplikasyon gelişirse tespit edilirler. Rüptür ya da torsiyon gibi komplikasyonlara yol açan kitleler ise ani belirtilere neden olurlar. Cerrahi girişimlere yol açarlar. Bunun yanında, en sık karşılaşılan belirti pelvik ağrı olmakla birlikte, adet düzensizlikleri ve pelvik rahatsızlık hissi de görülebilir (3).
Klinikte en yaygın olan semptomlar abdominal ağrı ve kitledir. Kitleler özellikle çocuklarda pelvis boşluğunun hacminin yetersiz olması nedeniyle fazla büyümemiş olsalar bile abdomen boşluğuna taşarak batında şişlik oluşturabilirler. Torsiyon, kist rüptürü ve perforasyon gibi komplikasyonlar oluşursa gelişen akut batın sendromu sonucunda şiddetli ağrı, periton iritasyonu bulguları ya da batın içi kanama ortaya çıkabilir (5).

Bazı over tümörleri klinik bir belirti göstermeden ancak acil başvuru sonucunda yapılan araștırmada ya da operasyonda ortaya çıkarlar. Laparatomi esnasında tanı konulan tümörler azımsanmayacak ölçüde olup \%25 oranındadır (5). Bu durum belirtilerin nonspesifik olmasından da kaynaklanabilir. Ayırıcı tanıya giren durumları iyi değerlendirmek gereklidir. Bu olgulara yanlışlıkla ergen ve çocuklukta yaygın olarak rastlanan apandisit, intususepsiyon ya da volvulus tanıları konulabilir. Bu nedenle, pediatrist ve pediatrik cerrahlar abdominal ağrı ya da batında kitle yakınması ile başvuran olgularda over tümörlerini düşünmeli ve dışlamalıdırlar (5).

Adneksiyal kitle ile başvuran olgularda ilk olarak sistemik bir değerlendirme için genel fizik muayene yapılmalıdır. Pelvik değerlendirme genellikle daha kısıtlı bir muayene yöntemi olan rektal tuşe ile yapılır. Rektal muayene pelvis içindeki tümörler için yardımcı olabilir. Fakat batın içindeki tümörleri saptamak için yetersiz bir yöntemdir. Bu nedenle tanı için görüntüleme teknolojisinden yararlanmak gerekmektedir. Ultrasonografi (USG) başta olmak üzere Doppler USG, Bilgisayarlı Tomografi (BT), Magnetik Rezonans Görüntüleme (MRG) mutlaka devreye girmektedir (5).

USG öncelikle gebelik olmadığını kanıtlamak için kullanılmalıdır. Bunun yanında, kitlenin solid ve kistik özelliklerini ortaya çıkarması ve kolay uygulanabilir olması en tercih edilen yöntem olmasını sağlamıştır. Abdominal BT ya da MRG sayesinde ise kötü huylu tümör varsa yayılımı, kalsifikasyonlar ve metastaz varlığı saptanabilir. Serumda bakılan tümör belirteçleri de tümörün cinsi ve malignite durumu konusunda fikir verebilirler. Bu amaçla alfa- fetoprotein, $\beta-\mathrm{HCG}, \mathrm{CA}-125$ gibi çeşitli tümör belirteçleri kullanılmaktadır (9).

Over tümörlerinde kullanılan belirteçler özgül olmamakla beraber tanı ve takipte büyük yararlar sağlamaktadırlar. Epitelyal over tümörlerinde CA-125, endodermal sinüs tümöründe alfa-fetoprein (AFP), koryokarsinomada $\beta$-HCG, disgerminomada laktat dehidrogenaz (LDH), granuloza hücreli tümörlerde inhibin ve Müllerian inhibe edici madde (Mullerian Inhibiting Subtance- MIS), Sertoli-Leydig hücreli tümörlerde testosteron ve gastrointestinal kökenli tümörlerin over metastazı olan Krukenberg tümöründe karsinoembriyonik antijen (CEA) klinik uygulamalarda yerini almıştır. Halen araştırma yapılan çok sayıda tümör belirteci bulunmaktadır (10).

Ergenlerde adneksiyal kitle ile karşılaşıldığında gebelik olasılığı her zaman akılda tutulmalı ve gebelik olmadığından emin olmak için serumda $\beta$-HCG ve USG ile değerlendirme öncelik olmalıdır (10). Gebelik dışlandıktan sonra başvuru esnasındaki klinik duruma uygun bir yaklaşım tarzı izlenebilir.

Adneksiyal kitle bulunan ergenler farklı klinik tablolar ile karşımıza çıkarlar. Buna göre yaklaşım tarzında da değişiklikler 
olabilir. Pelvik ya da abdominal kitlenin yanında endokrin bulguların da eşlik etmesi etiyolojik araştırma gereksinimini ortaya çıkarır. Bu yaş grubunda pubertas prekoks ya da diğer endokrin bozukluklar ile birlikte adneksiyal kitleler bulunduğunda hormonal olarak etkin tümörleri düşünmek yerinde olacaktır. Diğer bir başvuru şekli acil olarak hastaneye gelmektir. Klinik belirtisi olmayan ya da over tümörü için spesifik olmayan belirtileri olanlar da birden başlayan bulantı, kusma, periton bulguları ve batın içinde kanamaya işaret eden değişiklikler ile acil başvuruda bulunabilirler. Bu durumda en olası tanı over torsiyonu olduğundan organ kaybını önlemek için derhal acil cerrahi girişim gereklidir. Buna karşılık, fonksiyonel folikül kistleri olduğu düşünülen ergenlerde ise en uygun yaklaşım bekle-gör şeklinde ve oral kontraseptifler verilerek koruyucu bir izlem olmalıdır (2).

Ergenlerde koruyucu yaklaşım tarzı esastır. Çünkü overler bu yaş diliminde sadece doğurganlık ve üreme işlevi için değil aynı zamanda ergenin yapısal ve cinsel gelişiminin olgunlaşmasının tamamlanması için salgıladığı hormonlarla endokrin işlevi nedeniyle de önemlidir (5). Adneksiyal kitleye yaklaşım prensiplerini belirleyen ana etken budur.

Perimenenarşeal ve perimenopozal dönemlerde fonksiyonel over kistlerine çok sık rastlanır. Ultrason incelemesi bu tür kistlerin belirlenmesini kolaylaştırmaktadır. Fonksiyonel over kistlerinde kabul edilen birincil yaklaşım bekle-gör şeklinde izlemdir. En az 6 hafta bekledikten sonra yapılan ultrason tekrarına göre karar verilir. Bu kistlerin büyük bir bölümü iki adet döneminden sonra kaybolurlar. Bu bekleme döneminde kombine oral kontraseptif uygulamasını yeğleyen klinisyenler bulunmaktadır. Altta yatan düşünce gonadotropinlerin etkisini baskılayarak over işlevlerini düzene sokmaktır. Fakat yapılan çalışmalarda bekle-gör yaklaşımına bir üstünlüğü kanıtlanmış değildir. Tekrarlanan USG'de gerileme yoksa izlenecek yol cerrahi girişimdir (11). Seçilecek cerrahi yaklaşım olarak minimal invaziv özelliklerinin yanında hem tanı hem de tedavi olanakları sağlayan laparoskopik girişim uygun olgularda öncelikle düşünülmelidir. Over torsiyonu durumlarında organın torsiyonunun açılması ve bir süre kanlanma durumunun değerlendirilmesi denenmelidir. Kanlanması geri dönen olgularda tekrar torsiyon olasılığını ortadan kaldırmak amacıyla ooforopeksi yapılması ise tartışmalıdır. Laparatomi malignite düşünülen olgularda tercih edilecek yaklaşımdır. Selim kistlerde ise organın kistik bir kısmının çıkarılarak geride mümkün oldukça over dokusu bırakılmalıdır. Koruyucu cerrahi olarak ooforektomi yerine ovarian kistektomi uygun olgularda tercih edilmelidir (2). Bu yaklaşımı destekleyen bir çalışmada 139 sağlıklı ergen foliküler fazda USG takibine alınmıştır. Bu takip esnasında over kisti saptanan $17(\% 12,2)$ olguda üç aylık bir izlem süresinin sonunda kistlerin kendiliğinden ortadan kaybolduğu gözlenmiştir. Östrojen-progesteron içeren kombine oral kontraseptif kullanılan 6 olgudan 4 tanesinde 2-6 aylık bir zaman zarfında etkin bir tedavi sağlanmıştır. Kalan iki olguda yapılan cerrahi girişimde birinde kistik teratom ve diğerinde basit folikül kisti saptanmış ve ergenlerde over kistlerinin seri ultrasonla takip edilmesinin uygun yaklaşım olduğu kabul edilmiştir (12).
Adneksiyal kitlesi ile birlikte pelvik ağrısı olan ve yaş ortalaması 15,36 $\pm 1,6$ olan 49 olguya yapılan cerrahi girişim sonuçları bildirilmiştir. Bu olgulardan 45 tanesinde laparoskopik yaklaşım kullanılmıştır. Sonuç olarak, olguların \%9,52'sinde akut over torsiyonu, \%55,1'inde over neoplazması bulunmuş, buna karşılık kötü huylu tümöre rastlanmamıştır. Gerçek over neoplazmalarının ergende yaygın cerrahi endikasyon oluşturduğu ve uygun olgularda minimal invaziv girişimin emin bir yaklaşım olduğu gösterilmiştir (3).

Hastanın klinik durumuna göre cerrahi yaklaşım şekline karar verilmelidir. Selim olduğu düşünülen adneksiyal kitlelerde laparoskopik yaklaşım kabul edilebilir bir seçenektir. Fakat malignite şüphesi olan olgularda laparatomi kaçınılmaz olmaktadır (5).

Ergende over tümörlerinde primer yaklaşım koruyucu cerrahidir. Kötü huylu tümörlerde evreleme hastalığın yaygınlığını belirlemek ve operasyon sonrası tedavi şeklini planlamak için gereklidir (9).

Over tümörlerine cerrahi girişimde bulunan merkezlerde mutlaka donmuş kesit (frozen section) olanakları bulunmalı ve sonuç kötü huylu çıktığı zaman radikal kanser cerrahisi ve evreleme yapabilecek jinekolojik onkoloji yan dal uzmanları olmalıdır (11).

Evreleme cerrahisinde genel olarak batına girildikten hemen sonra sitolojik inceleme için batın yıkantı sıvısı alınır. Ardından kapsamlı bir abdominal ve pelvik eksplorasyon yapılmalı, şüpheli alanlardan biyopsiler alınmalı, pelvik ve para-aortik lenf nodlarının örneklenmesi ve omentektomi işlemleri ile devam edilmelidir (9).

Ergenlerde fertilitenin korunması amacıyla overlerden mümkün olan en az miktarda fakat tanı ve tedavi için yeterli olacak şekilde dokunun çıkarılması temel prensiptir. Overlerde yapılabilecek en sınırlı cerrahi işlem kistektomidir (2). Unilateral salpingo-ooforektomi ise over dokusunun tamamının tutulduğu ve koruyucu cerrahinin mümkün olmadığı durumlarda tüple birlikte çıkarılmasıdır (5).

Evre I over kanserli menarş öncesi kızlarda overe sınırlı tümörlerde koruyucu yaklaşımla unilateral salpingo-ooforektomi yapılabilir. Over dışına taşmış tümörlerde ise daha radikal bir yaklaşımla bilateral salpingo-ooforektomi ve histerektomi yapılmalıdır (5). İleri evre over kanserlerinde fertilite koruyucu cerrahinin yeri yoktur. Erişkinlerde olduğu gibi tümör küçültücü cerrahi prensiplerine uymak yerinde olur.

Ergenlik çağı tümörleri arasında önemli yeri olan bazı neoplazmalarda yaklaşım şekillerini özel olarak gözden geçirmekte yarar vardır. Bunlar içinde önde gelen tümör over teratomlarıdır. Teratomların ergenlik döneminde en sık rastlanan tümör olduğu bilinmektedir. Bebeklerde teratomlar daha ziyade over dışındaki vücut bölgelerinde belirgin olarak daha sık görülür. Hormon ve gonadotropinlerin yüksek düzeyde olduğu puberte dönemi en sık karşımıza çıktıkları zaman dilimidir. Over teratomlarının 9 yaşından önce kötü huylu olma olasılığı oldukça yüksektir (9).

Cerrahi yaklaşım ve evreleme prensipleri genel yaklaşımdan fazla bir fark göstermemektedir. Tek taraflı koruyucu bir yaklaşım ile birlikte karşı overin değerlendirilmesi, sitolojik örnek alınması, omentumun çıkarılması ve varsa periton 
implantlarından biyopsiler alınması şeklindedir. Kemoterapi planlanan olgularda apendektomi de önerilmektedir (9).

Disgerminom radyasyona oldukça hassas bir tümör olmasına rağmen operasyon sonrasında bütün tümör tipleri ve evrelerde kemoterapi, radyoterapiye birçok üstünlüğü ile tercih edilmektedir. Ayrıca kemoterapi fertilite üzerine radyoterapiye göre daha az olumsuz etkiye sahiptir. Overin germ hücreli tümörlerinde standart postoperatif yaklaşım kombinasyon kemoterapisi șeklindedir. Bu alanda cisplatin türevleri yaşam oranlarında sağladıkları belirgin artışla bu tip tümörlerin tedavisinde yeni bir çı̆̆ır açmışlardır. Son zamanlarda karşıt over ve uterusta tutulum olmayan olgularda fertilite koruyucu yaklaşımın yeri, uygulanabilirliği ve emniyeti lehte birçok çalışma ile kanıtlanmıştır (9).

Disgerminomların \%75'i yaşamın ilk yirmi, otuz yılı içinde ortaya çıktığından özellikle ergenlik dönemini ilgilendiren bir tümördür (13). Erkeklerde görülen seminomun kadınlardaki karşılığı olan bu tümörlerin tedavisinde erkek hastaların tedavisinden elde edilen veriler esas alınmıştır. Germ hücrelerinden köken almakta olan disgerminomlar gonadogenezin cinsel olarak henüz farklılaşmamış olduğu evreden kaynaklanmaktadırlar. Diğer germ hücreli tümörlerde pek rastlanmayan bilateral olma olasılığı (\%10-15) yüksek olan tümördür (13). Yaklaşım bu özelliğe göre şekillendirilmelidir. Bazen LDH ve HCG düzeylerinde yüksekliklere neden olarak diğer germ hücreli tümörlerle belirteç yönünden karışabilir (13). Koruyucu cerrahi yaş gereği ön plandadır. Disgerminomlarda yaklaşım overe sınırlı olgularda tek taraflı koruyucu cerrahi, ancak batın içi yayılım bulgusu olanlarda radikal yaklaşım ile tümör küçültücü cerrahidir (13).

Gonadoblastoma daha nadir olarak karşımıza çıkar. Gonadal disgenezi olan ve özellikle bir kromozomu Y olan olgularda görülür. Bu durumda diş genital organlar tam olarak maskülinizasyon gösteremezler. Bu şekilde başvuran olgularda tanıda USG ve BT gibi görüntüleme yöntemleri ön plandadır. Kendileri malign olmamakla birlikte kötü huylu germ hücreli tümörlerin kaynağı olmaları nedeniyle profilaktik gonadektomiyi gerektiren bir tümördür. Bazen anormal miktarlarda östrojen üreterek olumsuz klinik tablolara yol açarlar (7).

Sertoli-Leydig hücreli tümörlerde hormonal aktif tümörlerdir. Sertoli hücreleri östrojen ve Leydig hücreleri androjen üretirler. Klinikte karşımıza baskın olan hormonun etkileri ön planda olmak üzere feminizasyon, virilizasyon ya da pubertas prekoks bulguları ile gelirler. Kemoterapi ve radyoterapiye germ hücreli tümörlere göre dirençli olduklarından tedavi için en etkin seçenek cerrahidir (7).

Ergenlerde over tümörlerinde operasyon yaklaşımı tümörün tipi, evresi, derecesi, cerrahi girișimin șekli, kalan tümör dokusunun miktarı ve hastanın genel durumu gibi birçok özelliğe bağlı olarak değişkenlik göstermektedir. Genel olarak, disgerminom dişındaki germ hücreli tümörler kemoterapiye son derece hassastır (14). Disgerminom hem kemoterapiye hem de radyoterapiye çok iyi yanıt verir. Radyoterapi fertilite üzerine daha olumsuz etki yaptığından nadiren kullanılır. Kombinasyon kemoterapisi esastır. Bleomisin, cis-platin ve etoposid kombinasyonu kabul gören bir kemoterapi şeklidir. Alfa-fetoprotein ve $\beta$-HCG takipte son derece yararlıdır ve yükselmesi yinelemenin bir belirtisidir (14).

Ergenlerde olgu sayıları sınırlı olduğundan ve tam bir yaklaşım birlikteliği sağlanamadığından kesin bir algoritma oluşturmak zordur. Fonksiyonel ve fizyolojik over kisti oluşumları, spektrumun diğer ucundaki çok ciddi kötü huylu tümörlerle birlikte adneksiyal kitle grubunu oluşturmaktadır. Bu yelpazede fonksiyonel olduğu düşünülen olgularda primer yaklaşım bekle-gör yaklaşımıdır. Buna karşıllk, diğer olgularda temel ilke organ koruyucu yaklaşımdır. Kötü huylu tümörlerde buna evreleme eklenmelidir. Yaygın tümörlerde ise tümörü ortadan kaldıran daha radikal organ ekstirpasyonları ve tümör küçültücü yaklașım devreye girmektedir. Operasyon sonrası yaklaşım ise genel olarak cisplatin içeren bir kombinasyon kemoterapisidir. Bütün bu tedavileri uygularken ergenin gelișimi, psikolojisi, fertilitesinin korunması ve sonraki tedavi süreci de dikkate alınarak multidisipliner bir yaklaşım ön planda olmalıdır.

\section{Kaynaklar}

1. Drake J. Diagnosis and management of the adnexal mass. Am Fam Physic 1998; 57: 2471-80. (Abstract)

2. Davis AJ. Pediatric and adolescent gynecology. In: Gibbs RS ed(s). Danforth's Obstetrics and Gynecology. 10th ed. Philadelphia: Lippincott Williams \& Wilkins, 2008: 555-66.

3. Kocak M, Beydilli G, Dilbaz S, Tasci Y, Haberal A. Adnexal masses in adolescent girls with pelvic pain: report on 63 patients. Gynecol Surg 2008; 5: 203-7. (Abstract)

4. Pienkowski C, Baunin C, Gayrard M, et al. Ovarian masses in adolescent girls. In: Sultan C (ed): Pediatric and Adolescent Gynecology. Evidence-based clinical practice. Endocr Dev. Basel: Karger, 2004; 7: 163-82.

5. Muram D. Çorbacıoğlu A çev (ed)s. Pediatrik ve Adolesan Jinekoloji. In: Decherney AH, ed. "Current Diagnosis and Treatment" Serisi. Güncel Obstetrik ve Jinekoloji Tanı ve Tedavi. 10th ed. Ankara: Güneş Tıp Kitabevleri, 2010: 540-69.

6. Hassan E, Creatas G, Deligeorolgou E, Michalas S. Ovarian tumors during childhood and adolescence. A clinicopathological study. Eur J Gynaecol Oncol 1999; 20 : 124-6. (Abstract)

7. Herzog C. Gonadal and Germ cell Tumors. In: Behrman RE ed (s). Ne Ison Textbook of Pediatrics. 17th Ed. Philadelphia: Saunders, 2004; 1723-4.

8. Pierce GB, Abell MR. Embryonal carcinoma of the testis. Pathol Annu 1970; 5: 27-60.

9. Helikson ME. Teratoma 101. In: Ziegler MM ed. Operative Pediatric Surgery. USA: Mc Graw-Hill Companies, 2003; 1198-9.

10. Davidson SA. Management of adnexal mass. In: Gibbs RS ed (s). Danforth's Obstetrics and Gynecology. 10th ed. Philadelphia: Lippincott Williams \& Wilkins, 2008; 161-72.

11. Tzadik M, Purcell K, Wheeler JE. Onan A cev ed. Over ve tüplerin benign hastalıkları. In: Decherney AH (eds). " Current Diagnosis and Treatment" Serisi. Güncel Obstetrik ve Jinekoloji Tanı ve Tedavi. 10th ed. Ankara: Güneş Tıp Kitabevleri, 2010; 654-61.

12. Porcu E, Venturoli S, Dal Prato L, Fabbri R, Paradisi R, Flamigni C. Frequency and treatment of ovarian cysts in adolescence. Arch Gynecol Obstet 1994; 255: 69-72. (Abstract) / (PDF)

13. Larma J, Gardner GJ. Güngör M çev ed. Over kanseri . In: Fortner KB ed. John Hopkins Jinekoloji ve Obstetri El Kitabı. 3rd ed. Ankara: Güneș Tıp Kitabevleri, 2008; 508-25.

14. Williams SD. Malignant ovarian germ cell tumors. Gynecologic Cancer. In: Gershenson DM, ed. Controversies in management. Philadelphia: Elsevier Churchill Livingstone, 2004; 499-502. 